\title{
Mercury and methylmercury in aquatic sediment across western North America
}

Jacob A. Fleck ${ }^{1 *}$, Mark Marvin-DiPasquale ${ }^{2}$, Collin A. Eagles-Smith ${ }^{3}$, Joshua T. Ackerman ${ }^{4}$, Michelle A. Lutz ${ }^{5}$, Michael Tate ${ }^{5}$, Charles N. Alpers ${ }^{1}$, Britt D. Hall ${ }^{6}$, David P. Krabbenhoft ${ }^{5}$ and Chris S. Eckley ${ }^{7}$

${ }^{1}$ United States Geological Survey, California Water Science Center, 6000 J St., Placer Hall, Sacramento, California 95819

${ }^{2}$ United States Geological Survey, 345 Middlefield Road, Menlo Park, CA 94025, USA

${ }^{3}$ United States Geological Survey, Forest and Rangeland Ecosystem Science Center, Corvallis, OR

${ }^{4}$ United States Geological Survey, Western Ecological Research Center, Dixon Field Station, 800 Business Park Drive, Suite D, Dixon, California 95620, United States

${ }^{5}$ United States Geological Survey, 8505 Research Way, Middleton, WI 53562, USA

${ }^{6}$ Department of Biology, University of Regina, 3737 Wascana Parkway, Regina, SK, S4S 0A2, Canada

${ }^{7}$ United States Environmental Protection Agency, 1200 6th Ave, St. 900, OEA-095, Seattle WA 98101

*Corresponding author: e-mail: jafleck@usgs.gov, phone: 916-278-3063

Highlights:

- THg and MeHg concentrations of aquatic sediment compiled from $>11000$ sites across western NA

- Geospatial attributes were integrated with $\mathrm{Hg}$ and $\mathrm{MeHg}$ concentrations

- MeHg concentrations differed among landscape categories, trends differed from THg

- $\mathrm{THg}-\mathrm{MeHg}$ relationship was weak $\left(r^{2}=0.25\right)$ but significant across the landscape

- $51 \%$ of MeHg variation explained by within-site variability and landscape categories

Graphical Abstract
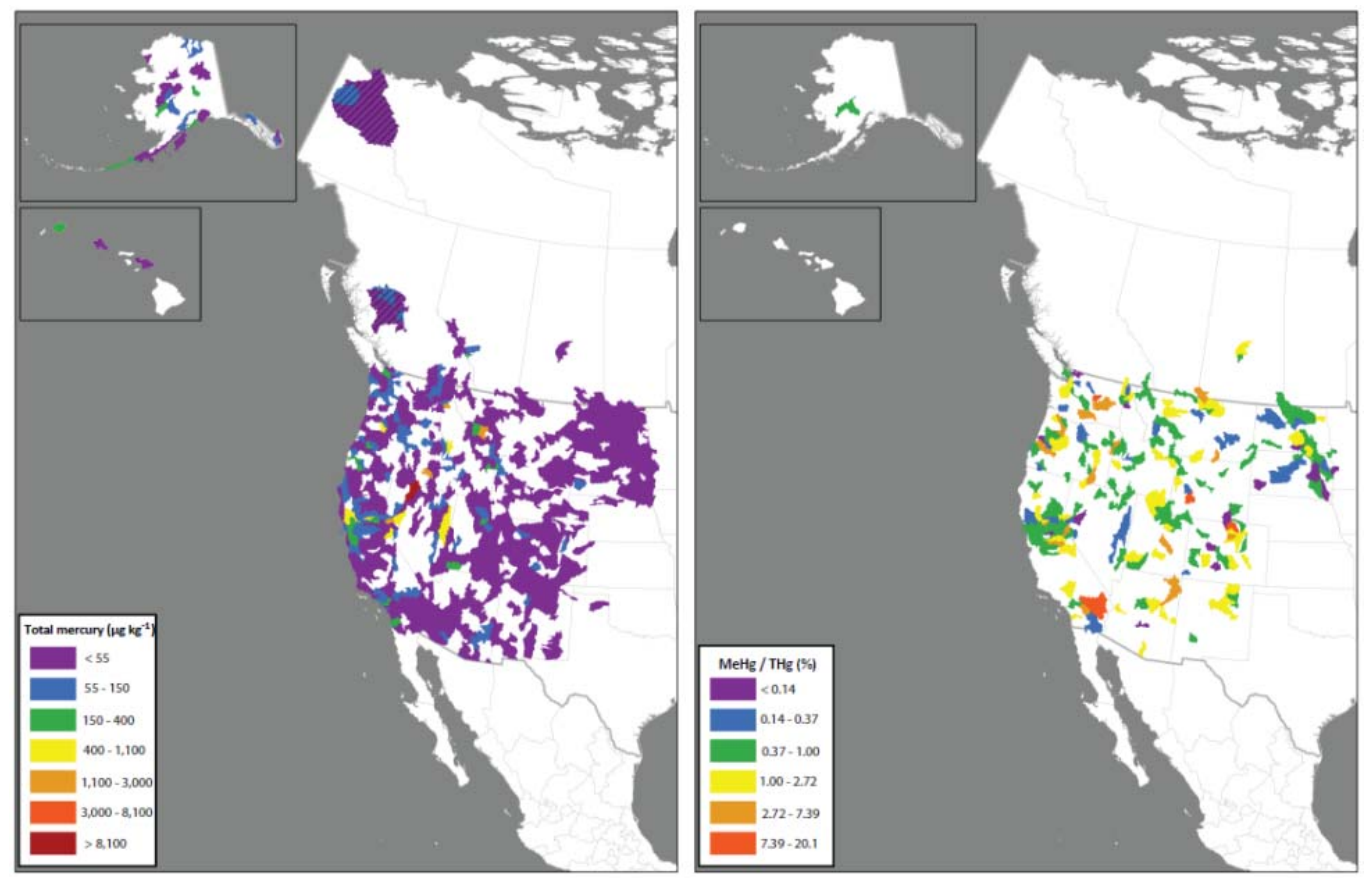


\begin{abstract}
Large-scale assessments are valuable in identifying primary factors controlling total mercury (THg) and monomethyl mercury ( $\mathrm{MeHg}$ ) concentrations, and distribution in aquatic ecosystems. Bed sediment THg and MeHg concentrations were compiled for $>16000$ samples collected from aquatic habitats throughout the West between 1965 and 2013. The influence of aquatic feature type (canals, estuaries, lakes, and streams), and environmental setting (agriculture, forest, open-water, range, wetland, and urban) on THg and MeHg concentrations was examined. THg concentrations were highest in lake (29.3 \pm $\left.6.5 \mu \mathrm{g} \mathrm{kg}^{-1}\right)$ and canal $\left(28.6 \pm 6.9 \mu \mathrm{g} \mathrm{kg}^{-1}\right)$ sites, and lowest in stream $\left(20.7 \pm 4.6 \mu \mathrm{g} \mathrm{kg}^{-1}\right)$ and estuarine $\left(23.6 \pm 5.6 \mu \mathrm{g} \mathrm{kg}^{-1}\right)$ sites, which was partially a result of differences in grain size related to hydrologic gradients. By environmental setting, open-water $\left(36.8 \pm 2.2 \mu \mathrm{g} \mathrm{kg}^{-1}\right)$ and forested $\left(32.0 \pm 2.7 \mathrm{\mu g} \mathrm{kg}^{-1}\right)$ sites generally had the highest THg concentrations, followed by wetland sites $\left(28.9 \pm 1.7 \mu \mathrm{g} \mathrm{kg}^{-1}\right)$, rangeland $\left(25.5 \pm 1.5 \mu \mathrm{g} \mathrm{kg}^{-1}\right)$, agriculture $\left(23.4 \pm 2.0 \mu \mathrm{g} \mathrm{kg}^{-1}\right)$, and urban $\left(22.7 \pm 2.1 \mu \mathrm{g} \mathrm{kg}^{-1}\right)$ sites. MeHg concentrations also were highest in lakes $\left(0.55 \pm 0.05 \mu \mathrm{g} \mathrm{kg}^{-1}\right)$ and canals $\left(0.54 \pm 0.11 \mu \mathrm{g} \mathrm{kg}^{-1}\right)$, but, in contrast to THg, MeHg concentrations were lowest in open-water sites $\left(0.22 \pm 0.03 \mu \mathrm{g} \mathrm{kg}^{-1}\right)$. The median percent $\mathrm{MeHg}$ (relative to $\mathrm{THg}$ ) for the western region was $0.7 \%$, indicating an overall low methylation efficiency; however, a significant subset of data $(n>100)$ had percentages that represent elevated methylation efficiency (>6\%). MeHg concentrations were weakly correlated with $\mathrm{THg}\left(\mathrm{r}^{2}=0.25\right)$ across western North America. Overall, these results highlight the large spatial variability in sediment THg and MeHg concentrations throughout western North America and underscores the important roles that landscape and land-use characteristics have on the MeHg cycle.
\end{abstract}

Keywords: spatial mercury patterns, Western North American Mercury Synthesis, WNAMS, mercury methylation, aquatic sediment 


\section{INTRODUCTION}

Aquatic bed sediment is an important zone of mercury $(\mathrm{Hg})$ methylation, the microbially-mediated process whereby inorganic $\mathrm{Hg}$ is converted to the more bioavailable form monomethyl mercury (MeHg) (Morel, 1998). Once converted to MeHg, this powerful neurotoxin can enter the food web and biomagnify up the food chain to concentrations that can threaten both human health and ecosystem function (Mergler et al., 2007; Weiner et al., 2003). Although MeHg concentrations generally correlate with total mercury (THg) concentrations over large spatial scales (e.g., Krabbenhoft et al., 1999), the strength of the correlation depends upon a number of factors. First, some fraction of the inorganic $\mathrm{Hg}$ must be available to the microbial populations that can methylate it, and the proportion of THg that is available for methylation is determined not only by the amount of inorganic $\mathrm{Hg}$ but also the biogeochemical conditions that affect its speciation (Bloom et al., 2003; Hsu-Kim et al., 2013; Jonsson et al., 2012; Sunderland et al., 2006). Also, biogeochemical conditions also affect the microbial activity that leads to MeHg production, as well as its degradation (Lambertsson and Nilsson, 2006; Ullrich et al., 2001). Then, physical transport processes may either concentrate MeHg in the area where it is produced leading to high MeHg concentrations or flush the MeHg away from the site of production at a greater rate than it can be replenished leading to low MeHg concentrations independent of net $\mathrm{MeHg}$ production rates.

Large-scale assessments have proven valuable in identifying primary factors controlling $\mathrm{THg}$ and MeHg concentrations in aquatic systems (Evers and Clair, 2005; Wiener et al., 2012). A national pilot study of 106 sites in 21 large river basins across the USA identified the importance of wetlands to MeHg concentrations in aquatic ecosystems (Brumbaugh et al., 2001; Krabbenhoft et al., 1999). Subsequent assessments have further identified the influence of urban development and forest cover in U.S. watersheds on THg and MeHg concentrations in both sediment and biota (Eagles-Smith et al., 2016a; Horowitz and Stephens, 2008; Wentz et al., 2014). Other studies have evaluated large-scale spatial effects on the geochemical factors controlling MeHg production in specific ecosystem types (Hall et al., 2008; Marvin-DiPasquale et al., 2009; Scudder et al., 2009).

The western North American landscape provides a unique setting with extremes in geological, geographical, and climatological characteristics. The combination of diverse Hg sources, habitat types, and geology, and extremes in topography, geography, and climate, create a complex mosaic of processes driving $\mathrm{Hg}$ cycling and bioaccumulation. One of the unique aspects of the West is the vast expanse of arid landscapes where water is scarce and extensively manipulated through a network of reservoirs, canals, and pipelines. Additionally, public lands comprise more than $60 \%$ of the total surface area in the American West, which includes numerous wildlife refuges, conservation areas, and preserves, where wetlands are managed to provide habitat for a diverse group of trust resources and endangered species. Because so much land is in the public domain, management efforts to reduce $\mathrm{Hg}$ risk may be more plausible in the West than in other geographic regions of North America. A better understanding of the distribution of $\mathrm{MeHg}$ across the landscape, and its relationship with $\mathrm{THg}$, would benefit attempts to manage $\mathrm{MeHg}$ risk. 
In this paper, the distribution of $\mathrm{THg}$ and $\mathrm{MeHg}$ concentrations compiled from a number of publicly available databases and literature for bed sediment are evaluated across a broad range of aquatic habitat types and environmental settings. Data are placed in the context of regulatory and advisory benchmarks as a means to assess areas of relative concern with respect to $\mathrm{Hg}$ contamination. Then, the relationship between MeHg and THg concentrations in bed sediment were examined across broad habitat types and environmental settings. These results further the understanding of $\mathrm{THg}$ and $\mathrm{MeHg}$ distribution across western North America, and affirm the importance of landscape factors in controlling MeHg concentrations.

\section{METHODS}

\section{Database compilation}

Aquatic bed sediment THg and MeHg concentration datasets from a wide variety of sources, including publicly available federal, state, and provincial databases, as well as published and unpublished data from individual laboratories and research projects were compiled in a single database (Table S1). The geographic scope of the data compilation encompassed 15 Western United States (U.S.) states and five Canadian provinces (Figure 1), which included all states and provinces containing land west of the front ranges of the Rocky Mountains, including Alaska and Hawaii, as well as those containing prairie potholes (Saskatchewan, North Dakota, and South Dakota). Data from Mexico were not available for inclusion except for a few values from lake sediment cores obtained in the literature search. All results compiled in the data set were evaluated for comparability. To achieve this, THg data results were constrained to include only total digests, whereas MeHg methods were generally more comparable across the databases. Despite attempts to include only THg results from complete digests with comparable $\mathrm{Hg}$ recoveries, the possibility of differences in the methodological recoveries of each database cannot be ruled out, although such an effect would likely only contribute to greater variation

in the dataset rather than a bias. All THg results with detection limits $>10 \mu \mathrm{gg}^{-1}\left(0.04 \mu \mathrm{gg}^{-1}\right.$ for $\left.\mathrm{MeHg}\right)$ or where data quality could not be effectively evaluated were then removed. This process eliminated nearly all data prior to 1990 . Some pre-1990 data were retained in the data set where sufficient documentation was provided for sample aliquots large enough to lower the effective THg detection limits to $\leq 10 \mu \mathrm{g} \mathrm{kg}^{-1}$. Data were then cross-checked using database codes that contained information about sample types, eliminating data where contradictions occurred that could not be resolved with the available metadata. For instance, it was not uncommon for sediment core samples to be labeled as "soil" and for soil samples to be labeled "bed sediment" in the databases. Because wetland environments represent the transition between aquatic and terrestrial systems, this distinction remains a challenge to consistency within and between all the databases queried. For the USGS National Water Information System (NWIS) database, some parameter codes explicitly state the matrix (e.g., suspended sediment versus bed sediment) and may have contradicted the selected matrix code for a specific result. In many cases, results with these contradictions were simply eliminated from the database unless there was clear evidence of the proper assignment to the bed sediment category to be included in this analysis. 
Bed sediment results were then grouped by sieve sizes. For this effort, "unsieved", " $<2 \mathrm{~mm}$ ", and "not reported" were grouped as "bulk sediment", whereas other sieve fractions were excluded for this analysis. One exception was the Canadian provincial databases where nearly all samples were sieved to less than $177 \mu \mathrm{m}$. Finally, all results were restricted to the surface sediment layer, for which 0-2 cm and 0-5 cm depth increments were most common. For results at or below the selected reporting levels (15\% of all THg data; $3 \%$ of all MeHg data), results were included as reported from data sources with lower reporting levels. For results reported as " $<$ " or "detected, not quantifiable" (DNQ) half the detection limit was assigned for the purpose of statistical analysis. All final compiled data were integrated into Microsoft Excel ${ }^{\circledast}, \mathrm{JMP}^{\circledR}$ and $\mathrm{ArcGIS}^{\circledR}$ programs for further analysis. Spatial data processing and mapping were accomplished using $\operatorname{ArcGIS}^{\circledR}$ and $\operatorname{ArcMAP}^{\circledR}$ software (Esri, Redlands, California, USA).

\section{Attribute and Geospatial Variable Assignments}

Extracting data from a number of databases resulted in a diverse range of supporting information for the THg results. There was a wide range in the level of descriptive metadata and relative quality with respect to accuracy and precision. Many THg results from the data compilation had little to no supporting information with respect to the site characteristics and sampling location. Therefore, to examine the compiled data in a consistent manner, only the THg and MeHg concentrations and GPS coordinates were included in the final compiled database. For each geo-referenced result, pointintersection attributes were assigned using a suite of GIS-based landscape coverages available on the web (Table S1-2). No single geospatial resource provided a consistent classification for habitat, land coverage, or water body type across the full data set. To achieve a consistently coded data set, a stepwise approach was used, illustrated in Figure S1-1a, assigning four general classes of aquatic 'feature type' loosely analogous to water body types (canal, estuary, lake, and stream). Those that were not classified by any of the geospatial layers or had conflicting classifications (a relatively small subset of the total) were cross-checked with site names and Google Maps (http://www.google.com/maps). Those with insufficient metadata and location uncertainty were left as "Unclassified" (Figure S1-1). Canadian data were limited to lakes and streams and were kept as reported in the data set, except prairie pothole wetlands which were included in the lake (closed drainage) feature category. Sites were then further categorized into six generalized classes of 'environmental setting' (agriculture, range, forested, openwater, urban, and wetland), which described a combination of habitat type and land cover as illustrated in Figure S1-2. The range category included all barren, shrubland and grassland categories identified in the land cover database. Environmental setting results that were not classified by any of the geospatial layers and/or available metadata were labeled as "not determined" (Figure S1-1b). All data were included in the subsequent development of maps, but those that were not classified were not included in statistical comparisons between groups.

To account for repeated measurements at the same location, all results were assigned a unique site ID as determined by the reported coordinates (latitude and longitude, in decimal degrees) in their respective databases. Coordinates were converted where necessary into decimal degrees. It is possible that samples from a single site may be represented as separate sites, if different location coordinates were reported for the individual results imposed by differing precision and accuracy of the location data ranging from hundredths to hundred-thousands of decimal degrees in the data set. However, this was 
expected to have occurred for only a small fraction of the data and that this variability would be accounted for through a spatial binning. The binning was performed by assigning each geo-referenced result in the database to its appropriate hydrologic unit code (HUC). There are different levels of HUCs, from HUC2 to HUC12 (largest to smallest in areal coverage). The HUC8 scale represents a relatively uniform watershed unit approximately $1800 \mathrm{~km}^{2}\left(700 \mathrm{mi}^{2}\right)$ in size, although the actual size varies according to specific topographic and hydrologic factors. Geospatial attributes in the public domain were well represented at the spatial scale of the HUC8 compared to the other HUC scales. This normalization of scale also addressed concerns related to evaluating data over differing spatial scales (Bradley et al., 2012; Horowitz and Stephens, 2008). Also, recent efforts extended the HUC8 level boundaries into Canada, allowing the data to be binned at the HUC8 level across both the USA and Canada. This analysis was not applied to the few data located in Mexico.

\section{Statistical analyses}

All statistical analyses were conducted using JMP statistical software (Version 11.2, SAS, Cary, North Carolina). The first step was to use basic summary statistics to examine the occurrence and distribution of THg and MeHg concentrations in all bed sediment samples collected across the landscape, regardless of the spatial distribution of the sites and the number of repeated measurements at any single site. Because data sets for $\mathrm{THg}$ and $\mathrm{MeHg}$ differed substantially in spatial coverage, the THg data set was evaluated first, then the MeHg data set, followed by a separate analysis of the subset of data where both THg and MeHg were co-collected. There were only $68 \mathrm{MeHg}$ results from Canada, all from a single study in the prairie pothole region of the Great Plains (Table S1-1). Because the collection and analysis procedures for these Canadian samples match those for the U.S. data set, all MeHg data were pooled for further analysis and discussion of MeHg statistics.

Next, a global Linear Mixed Effect (LME) ANCOVA model was developed to assess statistical differences, while simultaneously accounting for: a) within-site temporal variation where multiple samples were collected; b) among-site spatial variation across the landscape (at an approximate 1800 $\mathrm{km}^{2}$ scale, including intrinsic larger-scale effects such as longitudinal, latitudinal, ecoregion, climatological, and altitudinal characteristics); c) differences in temporal resolution of sampling efforts; and d) variation in repeated measures at specific sites. The global model included natural log (Ln) transformed concentration as the dependent variable, the sample HUC8 ID, feature type, and environmental setting classifications as fixed effects, and the unique site identifiers as a random effect. This approach allowed the creation of spatial maps representing least squares mean concentrations for HUC8s, and a statistical basis for comparison of the least squares means by classification groups. The HUC-based maps provide a statistically-based spatial visualization of concentration, accounting for repeated measurements, site type, and the integrated characteristics of the HUC8 grouping (e.g., elevation, precipitation, temperature), thus reducing the bias related to these factors in the visualization of the compiled database. Differences between categorical variables were evaluated at $\alpha=0.05$ using Tukey's Honest Significant Difference test.

Finally, the relationship between THg and MeHg was evaluated where data were paired within the original databases. First, simple bivariate linear regressions were evaluated for all data followed by a 
separate model, which included feature type and environmental setting as factors. The bivariate regression was then compared with the global ANCOVA model, using a likelihood ratio test, to determine if the additional variables significantly improved the model fit to the data. For this comparison, LnTHg and interactions between LnTHg and feature type and environmental setting were added as fixed effects in the global MeHg model.

\section{RESULTS AND DISCUSSION}

The final compiled database included total of $16418 \mathrm{THg}$ results from 11103 unique sites located in 545 HUC8s; 3233 MeHg results from 1877 sites in 244 HUC8s; and 2474 sample pairs where both THg and MeHg were collected from 1516 sites in 236 HUC8s across western North America. Each unique site, as identified by unique GPS coordinates, was represented by anywhere from one to 114 sample results for THg and one to 68 sample results for $\mathrm{MeHg}$, and each HUC8 was represented by one to 761 unique sites for $\mathrm{THg}$ and one to 450 unique sites for $\mathrm{MeHg}$.

\subsection{Total Mercury}

Bed sediment THg concentrations ranged over five orders in magnitude, from less than $10 \mu \mathrm{gg}^{-1}$ (lower limit of reporting) widely scattered across the entire landscape to $303255 \mathrm{\mu g} \mathrm{kg}^{-1}$ at a lake in eastern Nevada. A number of gold and mercury mine sites in California, Nevada, and Alaska also had concentrations near to or exceeding $100000 \mu \mathrm{gg}^{-1}$ (Figure 1). United States databases contained the vast majority of the high THg concentrations in the compiled data set; however, there was a maximum concentration of $13902 \mu \mathrm{g} \mathrm{kg}^{-1}$ at a forested stream site in the Mackenzie and Selwyn Mountains of the Yukon Territory. Median and $90^{\text {th }}$ percentile THg values were higher in the bulk sediment than in the sieved sediment from the provincial databases. The sieved $(<177 \mu \mathrm{m})$ sample data set had a median THg of $58 \mu \mathrm{g} \mathrm{kg}^{-1}$ and a 90th percentile of $130 \mu \mathrm{g} \mathrm{kg}^{-1}$. Median THg for bulk sediment ( $91 \mathrm{ug} \mathrm{kg}^{-1}$ ) was $57 \%$ higher than the median THg for the sieved data set; the 90th percentile ( $513 \mathrm{ug} \mathrm{kg}^{-1} ; \mathrm{N}=1861$ ) was nearly four times higher.

\section{< INSERT FIGURE 1 NEAR HERE >}

Figure 1. Map showing the distribution of THg concentrations of individual aquatic bed sediment samples across the western North American landscape. Figure A shows concentration data for all samples with low values overlaid on top of higher values. Figure B shows data for samples with concentrations greater than $400 \mu \mathrm{g} \mathrm{kg}^{-1}$ for easier visualization of the higher concentration locations. Symbol size and color are for visualization purposes only. Symbol colors reflect regulatory targets and benchmark screening levels, as summarized in Table 1, but also closely reflect the natural log distribution across the entire dataset. Despite the linkage to regulatory and benchmark concentrations, the concentration bins used in this assessment are not meant to imply risk but to provide a standardized framework for comparison.

There are a number of sediment THg concentration-based screening levels established for the protection of wildlife and human health that provide context to these concentrations and distributions (MacDonald et al., 2000; Randall et al., 2013). Overall, the compiled data set is heavily weighted toward the low end of the concentration range and many of the results are below any screening or advisory levels, but a substantial number of results were above benchmarks for potential risk to both wildlife and 
human health (Table 1). Fewer than $10 \%$ of the sieved samples exceeded the benchmark effects level, the lowest screening level for aquatic health effects $\left(170 \mathrm{\mu g} \mathrm{kg}^{-1}\right)$ and only three out of 5045 exceeded the severe, or adverse, benchmark effect level $\left(2000 \mu \mathrm{g} \mathrm{kg}^{-1}\right)$. By comparison, the bulk sediment set had at least $10 \%$ of samples exceed the probable effect level for freshwater sediment in Canada $\left(490 \mu \mathrm{g} \mathrm{kg}^{-1}\right)$ and the clean-up screening level for the state of Washington $\left(590 \mu \mathrm{g} \mathrm{kg}^{-1}\right)$ and nearly $2 \%$ (more than 200 of 11000 samples) exceed the adverse benchmark effect level $\left(2000 \mu \mathrm{g} \mathrm{kg}^{-1}\right)$. When comparing the distribution of the results with the spatial distribution in the map, it appeared that the data set is heavily weighted by a bias in sampling frequency and/or data density in contaminated locales, such as was observed in the soil THg data sets (Obrist et al., this issue).

Table 1. Relation of THg map color bins to screening levels and threshold concentrations established for the safety of wildlife and human health.

\section{< INSERT TABLE 1 NEAR HERE >}

When accounting for repeated measurements at a single sampling location, significant differences among HUC8 units were evident across the landscape (bulk sediment: $F_{519,5711}=11.19, p<0.0001$; sieved sediment: $F_{24,4729}=50.41, p<0.0001$ ). It should be noted that a high degree of uncertainty existed within the modeled least squares mean THg concentrations for some HUC8s (Figure S2-1). Least squares mean THg concentrations exceeded the $200 \mu \mathrm{g} \mathrm{kg}^{-1}$ benchmark in only $5 \%$ of the HUC8s (6\% in U.S. and $0 \%$ in Canada), a result aligned with the distribution of soil THg across this region (Obrist et al., this issue), and the highest concentrations occur in areas of known native cinnabar deposits and/or historic $\mathrm{Hg}$, gold or silver mining activity (Alpers et al., 2005; Bouse et al., 2010; Gray and Bailey, 2003; Lawrence, 2003; Rytuba, 2003; Singer et al., 2013).

\section{<INSERT FIGURE 2 NEAR HERE >}

Figure 2. Map showing the spatial distribution of HUC8-based least squares mean THg concentrations for A) the complete THg data set and B) the subset of the THg data where MeHg was also measured. Crosshatching indicates HUCs where all samples were sieved.

HUC8-based least squares mean THg concentrations indicate a potential grain-size effect between the bulk sediment and the sieved sediment. The act of sieving effectively removed the coarse and medium sand fractions from the samples, which are typically lower in THg concentration than finer grained particles, leading to elevated THg concentrations in sieved samples (Fleck et al., 2011; Nater and Grigal, 1992). However, lack of a grain-size effect on THg concentration has been observed in stream sediment downstream from natural sources (e.g., Bosworth and Morris, 2009). Although there are large areas where natural geologic sources of THg determine aquatic sediment concentrations in the Western U. S., only a small portion of the entire western landscape is represented by this condition, particularly the $\mathrm{Hg}$ ore belts located in the Coast Ranges along the Pacific coast and isolated deposits in the Great Basin and Rocky Mountains (Rytuba, 2003). Even areas contaminated from historical mining activities, where elemental $\mathrm{Hg}$ was used to recover gold and silver from non-Hg bearing deposits, exhibit a grainsize effect with increasing THg concentration associated with finer grain sizes (Alpers et al., 2006; Fleck et al., 2011; Hunerlach et al., 2004). 
Significant differences in THg concentrations were observed among the general categories of feature type and environmental setting (Figure 3). Among feature types, lake $\left(29.3 \pm 6.5 \mu \mathrm{g} \mathrm{kg}^{-1}\right)$ and canal $\left(28.6 \pm 6.9 \mu \mathrm{g} \mathrm{kg}^{-1}\right)$ had the highest THg concentrations, whereas stream $\left(20.7 \pm 4.6 \mu \mathrm{g} \mathrm{kg}^{-1}\right)$ and estuarine $\left(23.6 \pm 5.6 \mathrm{~m} \mathrm{~kg}^{-1}\right)$ sites had the lowest $\left(F_{4,5497}=14.44, p<0.0001\right.$; Figure 3a). No difference was observed between lakes $\left(41.5 \pm 6.2 \mu \mathrm{g} \mathrm{kg}^{-1}\right)$ and streams $\left(46.0 \pm 6.8 \mu \mathrm{g} \mathrm{kg}^{-1}\right)$ in the sieved data set from Canada $\left(F_{2,4736}=1.28, p=0.28\right.$; Figure $\left.3 a\right)$. The difference between lakes and streams in the bulk sediment, and the lack of a difference in the sieved samples, may be due to the grain size effect noted above, because streams tend to have larger grain size sediment than lakes due to the relative hydraulic gradients in these landscape feature types, with lakes representing lentic and streams representing lotic systems. Sieving the samples removed this feature-based grain size effect from the Canada data set. Canals and ditches tend to be relatively low-gradient environments (lentic) as well, explaining why this feature type may resemble lakes more than streams in terms of THg concentration.

General trends in differences among environmental settings were similar for the bulk $\left(F_{6,5402}=9.31\right.$, $p<0.0001)$ and sieved $\left(F_{4,4736}=14.66, p<0.0001\right)$ data sets, although not all settings were represented in the sieved data set. Forested (bulk $=32.0 \pm 2.7 \mu \mathrm{g} \mathrm{kg}^{-1}$; sieved $=47.6 \pm 11.2 \mu \mathrm{g} \mathrm{kg}^{-1}$ ) and open-water (bulk = $36.8 \pm 2.2 \mu \mathrm{g} \mathrm{kg}^{-1}$; sieved $=48.0 \pm 11.4 \mu \mathrm{g} \mathrm{kg}^{-1}$ ) sites generally had the highest least squares mean THg concentrations followed by wetland sites (bulk $=28.9 \pm 1.7 \mu \mathrm{g} \mathrm{kg}^{-1}$; sieved $=45.4 \pm 11.0 \mu \mathrm{g} \mathrm{kg}^{-1}$; Figure $3 b$ ), whereas rangeland (bulk $=25.5 \pm 1.5 \mu \mathrm{g} \mathrm{kg}$; sieved $=39.7 \pm 9.4 \mathrm{~g} \mathrm{~kg}^{-1}$ ), agriculture (bulk = $23.4 \pm 2.0 \mu \mathrm{g} \mathrm{kg}{ }^{-1}$; sieved $=15.8 \pm 11.6 \mu \mathrm{g} \mathrm{kg}^{-1}$ ) and urban (bulk $=22.7 \pm 2.1 \mu \mathrm{g} \mathrm{kg}^{-1}$; sieved = no data) sites generally had the lowest THg concentrations, a trend opposite of that observed in previous assessments across the U. S. where urban settings were elevated in THg (Horowitz and Stephens, 2008; Marvin-DiPasquale et al., 2009). It is difficult to speculate why THg concentration would differ between the broad characteristics that define the environmental settings categories; however, open-water sites and wetlands are depositional environments where finer-grained materials accumulate which may explain their relatively high THg concentrations. Forested sites are likely to have elevated THg relative to the rangeland and agricultural sites, because of the greater productivity and higher organic content of the forested sites which facilitates greater delivery and storage of $\mathrm{Hg}$ to these systems, leading to higher THg concentrations in the terrestrial soils (Obrist et al., this issue).

\section{$<$ INSERT FIGURE 3 NEAR HERE $>$}

Figure 3. Comparison of least squares mean concentration for A) THg by feature type, B) THg by environmental setting, C ) MeHg by feature type, D) MeHg by environmental setting, E) MeHg/THg by feature type, and F) MeHg/THg by environmental setting. Different letters next to the bars on the chart indicate significant differences between categories, capital letters were used for the bulk data set and small letters were used for the sieved data set.

\subsection{Methylmercury}

Sediment $\mathrm{MeHg}$ concentrations ranged over three orders of magnitude from below the reporting limit $\left(0.04 \mu \mathrm{g} \mathrm{kg}^{-1}\right)$ to $91 \mu \mathrm{g} \mathrm{kg}{ }^{-1}$ at the Alpha Mine tunnel and pit in California's Sierra Nevada gold mining region; however, sites in South San Francisco Bay, other gold mines in the Sierra Nevada, California, and the Great Salt Lake, Utah also had MeHg concentrations between 20 and $80 \mathrm{\mu g} \mathrm{kg}^{-1}$ 
(Figure 4a). Importantly, some of the highest MeHg concentrations occurred in areas with relatively low THg concentrations, particularly in the prairie pothole region of the Great Plains, parts of the Rocky Mountains, and the Great Basin. The Canadian provincial databases did not include MeHg (Table S1-1). MeHg concentrations were more evenly distributed across the landscape than $\mathrm{THg}$, as indicated in the representation of the colors in each concentration bin (Figure 4a). The median MeHg concentration was $0.70 \mu \mathrm{g} \mathrm{kg}^{-1}$ with a $90^{\text {th }}$ percentile value of $4.51 \mathrm{\mu g} \mathrm{kg}^{-1}$. It should be noted that the locations where MeHg was measured had generally higher THg concentrations than the larger THg data set, indicating a bias toward more contaminated sites for the sampling locations where data for $\mathrm{MeHg}$ were also collected (median = $129 \mathrm{\mu g} \mathrm{kg}^{-1} \mathrm{vs} 90 \mathrm{\mu g} \mathrm{kg}^{-1}$, respectively); however, the general spatial trends for $\mathrm{THg}$ in the full data set and the subset where MeHg data exist were similar (Figures 2a and 2b).

Unlike $\mathrm{THg}$, there are no established environmentally-relevant screening levels for $\mathrm{MeHg}$ in aquatic bed sediment; however, $\mathrm{MeHg} / \mathrm{THg}$ ratios are often used to determine the relative "methylation efficiency" of a system to identify areas of greater concern with respect to ecosystem risk (Kelly et al., 1995, Gilmour et al., 1998; Krabbenhoft et al., 1999; Sunderland et al., 2006). In the previous USGS national assessment, locations where $\% \mathrm{MeHg}$ relative to $\mathrm{THg}$ concentrations were greater than $6 \%$ corresponded with elevated MeHg concentrations in biota (Krabbenhoft et al., 1999). The $\mathrm{MeHg} / \mathrm{THg}$ ratio in this compilation was generally low across the landscape with a median value of $0.7 \%$ and a $90^{\text {th }}$ percentile of 3.1\%, although more than 100 locations exceeded the $6 \%$ benchmark (Figure $4 \mathrm{~b}$ ). Several other studies have reported similar central tendencies for $\mathrm{MeHg} / \mathrm{THg}$ ratios: estuarine sediment in southern Florida (0.8\%, Kannan et al., 1998), estuarine sites in New England (0.4\%, Taylor et al., 2012), reservoirs in Colorado ( $0.2 \%$ to $0.3 \%$, Gray et al., 2014$)$, and mine-dominated large-scale watersheds in the USA (1\%, Krabbenhoft et al., 1999). However, much higher mean MeHg/THg ratios were reported in northeastern lakes and streams (4\%, Loukmas et al., 2006) and watersheds across the USA $(3.2 \%$, Scudder et al., 2009), particularly in mixed agricultural-forested watersheds (10\%, Krabbenhoft et al., 1999).

\section{<INSERT FIGURE 4 NEAR HERE >}

Figure 4. Map showing the spatial distribution of individual sample results for A) surface sediment MeHg concentration and B) the ratio of $\mathrm{MeHg}$ to $\mathrm{THg}$, shown as a percentage, across western North America.

Modeled MeHg concentrations differed significantly among HUC8s across the landscape $\left(F_{243,1856}=\right.$ 3.06, $p<0.0001)$. Accounting for repeated measurements at the same locations did not alter the apparent distribution of MeHg across the landscape. As noted above for HUC8-based least squares mean THg concentrations, there is a large range in uncertainty based on internal variability and number of measurements at any site or HUC8 (Figure S2-3). Generally speaking, least squares mean MeHg concentrations were distributed more extensively across the landscape than were $\mathrm{THg}$ concentrations, illustrated in the $\mathrm{MeHg} / \mathrm{THg}$ ratio (Figure 5). However, some of the locations where high individual MeHg concentrations were observed contained low to moderate THg concentrations (e.g., prairie potholes in Canada). In this particular case, large temporal variations might be expected between repeated measures of $\mathrm{MeHg}$ at a single site due to hydrologic and climatological effects (e.g., Bradley et al., 2012; Heim et al., 2008; Ullrich et al., 2001), and extreme small-scale spatial variation in MeHg concentrations may be expected along a hillslope due to "hot spots" associated with unique 
biogeochemical conditions in edge environments (Lambertsson and Nilsson, 2006; Mitchell et al., 2009). However, it is important to note that analysis of a compiled data set at this scale cannot discriminate between these drivers of MeHg concentration. The HUC8-based least squares mean MeHg concentrations should be viewed as an indicator of the potential for any aquatic habitat within a specific HUC8 boundary to have a higher or lower $\mathrm{MeHg}$ concentration relative to the other similar aquatic habitats within other HUC8s as represented on the map.

\section{<INSERT FIGURE 5 NEAR HERE >}

\section{Figure 5. Map showing the spatial distribution of HUC8 least squares mean for A) MeHg concentrations and B) the ratio of $\mathrm{MeHg}$ to $\mathrm{THg}$, shown as a percentage.}

Significant differences in $\mathrm{MeHg}$ concentration and $\mathrm{MeHg} / \mathrm{THg}$ ratios were observed among our general categories of feature type ( $\mathrm{MeHg}, \mathrm{F}_{3,1497}=17.27, \mathrm{p}<0.0001 ; \mathrm{MeHg} / \mathrm{THg}, \mathrm{F}_{3,1060}=7.80, p<0.0001$ ) and environmental setting ( $\mathrm{MeHg}, \mathrm{F}_{5,1574}=24.51, \mathrm{p}<0.0001 ; \mathrm{MeHg} / \mathrm{THg}, \mathrm{F}_{5,1095}=10.76, p<0.0001$ ). Least squares mean MeHg concentrations for lakes $\left(0.55 \pm 0.05 \mu \mathrm{g} \mathrm{kg}^{-1}\right)$ and canals $\left(0.54 \pm 0.11 \mu \mathrm{g} \mathrm{kg}^{-1}\right)$ were approximately twice that of estuarine $\left(0.26 \pm 0.05 \mu \mathrm{g} \mathrm{kg}^{-1}\right)$ and stream sites $\left(0.31 \pm 0.03 \mu \mathrm{g} \mathrm{kg}^{-1}\right.$; Figure 3c). Ratios of $\mathrm{MeHg} / \mathrm{THg}$ by feature followed the same general ranking as $\mathrm{MeHg}$ concentration, but the differences were less pronounced (Figure 3d). For the least squares mean $\mathrm{MeHg} / \mathrm{THg}$ ratio, lakes $(0.9 \% \pm$ $0.1 \%)$ and canals $(1.0 \% \pm 0.1 \%)$ were higher than estuarine $(0.6 \% \pm 0.1 \%)$ sites and streams $(0.7 \% \pm$ $0.1 \%)$, a non-significant difference for this data set. The trends observed in least squares mean $\mathrm{MeHg}$ concentration (Figure 3e) were similar to those for $\mathrm{MeHg} / \mathrm{THg}$ ratio (Figure 3f) among environmental setting, with open water $\left(0.22 \pm 0.03 \mu \mathrm{g} \mathrm{kg}^{-1} ; 0.5 \% \pm 0.0 \%\right)$ and urban $\left(0.26 \pm 0.06 \mu \mathrm{g} \mathrm{kg}^{-1} ; 0.6 \% \pm 0.1 \%\right)$ sites lowest among the environmental setting categories, whereas wetland $\left(0.58 \pm 0.07 \mu \mathrm{g} \mathrm{kg}{ }^{-1} ; 1.0 \% \pm\right.$ $0.1 \%)$ and forested $\left(0.56 \pm 0.08 \mu \mathrm{g} \mathrm{kg}^{-1} ; 0.9 \% \pm 0.1 \%\right)$ were the highest. There are numerous landscape, climatological, and biogeochemical variables integrated within these general categories that likely contribute to these trends. Unfortunately, the wide range in scope and quality in the databases ancillary data and metadata limited the ability to examine these trends in a deterministic manner.

\subsection{Methylmercury and THg relationships}

The relationship between MeHg and THg has been used extensively to evaluate the relative risk between habitats without the difficulties and expense of measuring both $\mathrm{MeHg}$ and $\mathrm{THg}$ and methylation rates, which can be cost-prohibitive if applied across the landscape (Krabbenhoft et al., 1999). The benefit of a predictive relationship between the two variables is clear when comparing the number of results and the spatial coverage of the THg data set with that of the MeHg data set (Figure 2). However, numerous studies have shown inconsistency in the MeHg-THg relationships across habitats and seasons (Davis et al., 2012; Gilmour et al., 1998; Heim et al., 2007; Kannan et al., 1998; Kelly et al., 1995; Lambertsson and Nilsson, 2006). Examining the overall relationship and how it differs across the landscape may provide a more robust foundation for identifying, if not predicting, areas of greater concern.

This study addresses the relationship between sediment MeHg and THg concentrations across a larger spatial scale and greater variety of aquatic habitats, settings, and landscape characteristics than previous studies. Across these extensive gradients, a weak positive relationship between MeHg and THg 
concentrations was observed $\left(r^{2}=0.25 ; p<0.0001\right.$, Figure S3-1). Additionally, the slope and intercept of the relationship differed among feature type and environmental setting (Figure S3-1). Rangeland sites had a significantly lower slope $(0.32 \pm 0.03)$ than the other environmental settings that were similar to each other (e.g., wetland $=0.54 \pm 0.03$, open water $=0.50 \pm 0.04$ ), indicating the relatively low $\mathrm{MeHg}$ producing capacity of rangelands. The slope was highest in the urban setting $(0.65 \pm 0.12)$, but the difference was not significant among environmental settings except when compared to the rangeland slope. When accounting for feature type $\left(F_{3,1808}=0.54, p=0.65\right)$ and environmental setting $\left(F_{5,1803}=2.22\right.$, $\mathrm{p}=0.05$ ), the global model was able to explain $76 \%$ of the variation in the $\mathrm{MeHg}$ data. These results indicate that THg concentrations are generally a weak determinant of resulting MeHg concentrations in sediment across western North American aquatic habitats, and indicate that local biogeochemical drivers, such as feature type and environmental setting, are likely more important in determining MeHg concentrations. The full model better explained the MeHg data than THg alone $\left(D_{243}=937, p<0.0001\right)$. Further analysis of the within-HUC8 spatial attributes is warranted to identify and characterize the specific driving variables implicit in our categorization scheme and further the goal of predictive landscape-based models for MeHg concentrations and ecosystem risk.

\subsection{Implications}

The extensive landscape and water management activities that are commonplace in western North America present a potential opportunity to minimize the threats posed by mercury contamination. Because THg is a poor predictor of MeHg across the habitats in this vast region, management approaches focused on $\mathrm{THg}$ concentration as the means to reduce risk are likely to have limited effects. Although this decoupling between $\mathrm{THg}$ and $\mathrm{MeHg}$ has been recognized previously within specific studies, there has been general agreement on the effects that THg concentrations impose upon MeHg concentrations within and between habitats observed over large spatial scales. This phenomenon was not observed across the expanse of western North America and its diverse range of habitats. Instead, the importance of local environmental factors on $\mathrm{MeHg}$ concentrations highlights the need for a greater understanding of the environmental conditions that influence MeHg production, degradation, and transport across the landscape. Therefore, to further the understanding of health and environmental risks due to $\mathrm{Hg}$ contamination across the landscape, attention should be given to more comprehensive characterization of the aquatic habitats where $\mathrm{Hg}$ cycling is being investigated. Based on the degree of influence imposed by the coarse habitat categories available for use in this assessment, even a modest improvement in site characterization within, and its standardization across, studies would likely improve our predictive capability in assessing MeHg concentrations across the landscape. Simple site characteristics including: a) a standardized and detailed classification scheme for water body or wetland type (e.g., Cowardin et al., 1979); b) information about the location within the water body or wetland to address the issue of 'hot spots' in edge environments; c) water depth (both the overall maximum and average of the water body and the specific depth at the sampling location); d) an estimate of water velocity at the sampling location during collection to address variability imposed by transport; and e) land cover (both within the general area and at the specific sampling location) would provide a robust assessment of factors controlling MeHg concentrations. Addition of these site characteristics, combined with the recent advancements in geospatial information and analysis, as well as ancillary chemical 
measurements recommended in previous synthesis efforts (e.g., organic matter content, sulfate concentration, $\mathrm{pH}$ ), would greatly improve the understanding of habitat-related processes that affect MeHg production (e.g., Hall et al., 2008; Marvin-DiPasquale et al., 2009) and its ultimate fate in the food web (Eagles-Smith et al., this issue).

\section{CONCLUSIONS}

Aquatic bed sediment THg and MeHg concentrations from a wide array of aquatic habitats across western North America were compiled and statistically analyzed. Results indicated that $\mathrm{MeHg}$ concentrations at levels that pose a potential concern to the food web were more widespread across the landscape than THg concentrations were. As a result, MeHg concentrations were weakly $\left(r^{2}=0.25\right.$; $p<0.0001$ ) related to THg concentrations. Landscape features (e.g., lakes, streams) and environmental setting (e.g., wetland, forested, rangeland, urban) accounted for an additional $51 \%$ of the variation in MeHg concentrations, indicating that local biogeochemical conditions associated with habitat characteristics impose a predominant influence on the spatial distribution of $\mathrm{MeHg}$ in sediment across western North America, independent of THg concentration. Future efforts to elucidate factors controlling MeHg concentration in sediment would be improved with simple metrics aimed to characterize the habitat and its biogeochemical attributes during sample collection.

\section{ACKNOWLEDGEMENTS}

This work was conducted as a part of the Western North American Mercury Synthesis Working Group supported by the John Wesley Powell Center for Analysis and Synthesis, a joint venture of the U.S. Geological Survey and the National Science Foundation. We are thankful for additional support provided by the USGS Contaminant Biology Program. Additional funding for geospatial analysis was provided U.S. EPA Region 10 through a Regional Applied Research Effort (RARE) grant managed by ORD Principal Investigator Heather Golden (Ecological Exposure Research Division, National Exposure Research Laboratory) and Regional Science Liaison Bruce Duncan. We thank U.S. Geological Survey California Water Science Center colleagues Roger Fujii and Paul Work for general support and Mike Solt and Jim Orlando for technical assistance. The authors would also like to extend our appreciation to working group team members including Kiira Siitari, Joe Domagalski, George Aiken, Daniel Obrist, and Madeleine Turnquist. We would like to extend special thanks to Jim Wiener and David Evers for their leadership in the Mercury Synthesis series. Any use of trade, product, or firm names is for descriptive purposes only and does not imply endorsement by the U.S. Government.

\section{REFERENCES}

Alpers, C.N., Hunerlach, M.P., May, J.T., Hothem, R.L., 2005. Mercury contamination from historical gold mining in California: U.S. Geological Survey Fact Sheet 2005-3014, Version 1.1, 6 p., http://pubs.usgs.gov/fs/2005/3014.

Alpers, C.N., Hunerlach, M.P., Marvin-DiPasquale, M.C., Antweiler, R.C., Lasorsa, B.K., De Wild, J.F., et al., 2006. Geochemical data for mercury, methylmercury, and other constituents in sediments from 
Englebright Lake, California, 2002: U.S. Geological Survey Data Series 151, 95 p. http://pubs.usgs.gov/ds/2006/151/

Barnes H.L., Seward T.M., 1997. Geothermal systems and mercury deposits. In: Barnes HL, Ed. Geochemistry of hydrothermal ore deposits. John Wiley, N.J., pp. 699-736.

Bausch, N.J., Chasar, L.C., Scudder, B.C., Moran, P.W., Hitt, K.J., Brigham, M.E., et al., 2009. Data on mercury in water, streambed sediment, and fish from selected streams across the United States, 1998-2005: U.S. Geological Survey Data Series 307, 32 p., http://pubs.usgs.gov/ds/307.

Benoit, J.M., Gilmour, C.C., Heyes, A., Mason, R.P., Miller, C., 2003. Geochemical and biological controls over methylmercury production and degradation in aquatic systems. In: Cai, Y., Braids, O.C. (Eds.), Biogeochemistry of Environmentally Important Trace Metals, ACS Symposium Series, vol. 835.

Oxford Univ. Press, New York, pp. 262- 297.

Bloom, N. S., Preus, E., Katon, J., Hiltner, M., 2003. Selective extractions to assess the biogeochemically relevant fractionation of inorganic mercury in sediments and soils. Analytica Chimica Acta 479:233248.

Bosworth D., Morris, P., 2009. Bear Creek mercury inventory. Central Valley Regional Water Quality Control Board. Staff Report.

Bouse, R., Fuller, C., Luoma, S., Hornberger, M., Jaffe, B., Smith, R.E., 2010. Mercury-contaminated hydraulic mining debris in San Francisco Bay. San Francisco Estuary and Watershed Science, 8(1)

Bradley, P. M.; Journey, C. A.; Brigham, M. E.; Burns, D. A.; Button, D. T.; Riva-Murray, K., 2013. Intraand inter-basin mercury comparisons: Importance of basin scale and time-weighted methylmercury estimates. Environ. Pollut. 172:42-52.

Brumbaugh, W.G., Krabbenhoft, D.P., Helsel, D.R., Wiener, J.G., Echols, K.R., 2001. A national pilot study of mercury contamination of aquatic ecosystems along multiple gradients: Bioaccumulation in Fish. USGS/BRD/BSR-2001-0009, iii 25pp.

Canadian Council of Ministers of the Environment, 1995. Protocol for the derivation of Canadian sediment quality guidelines for the protection of aquatic life. Prepared by the Technical Secretariat of the CCME Task Group on Water Quality Guidelines. Ottawa

Cowardin, L.M., Carter, V., Golet, F.C., LaRoe, E.T., 1979. Classification of wetlands and deep water habitats of the United States. U.S. Fish and Wildlife Service, Washington, D.C., USA, FWS/OBS$79 / 31$.

Davis, J., Looker, R.E., Yee, D., Marvin-Di Pasquale, M., Grenier, J.L., Austin, C.M., et al., 2012. Reducing methylmercury accumulation in the food webs of San Francisco Bay and its local watersheds. Environ Res 119:3-26.

Eagles-Smith, C.A., Herring, G., Johnson, B., Graw, R., 2016a. Conifer density within lake catchments predicts fish mercury concentrations in remote subalpine lakes. Environmental Pollution 212: 27989.

Eagles-Smith, C.A., Ackerman, J.T., Willacker, J.J., Tate, M., Lutz, M., Fleck, J.A., et al., 2016b. Spatial and temporal patterns of mercury concentrations in freshwater fishes across the western US and Canada. Sci. Total Environ. [in this issue].

EC MENVIQ (Environment Canada and Ministere de I'Envionnement du Quebec), 1992. Interim criteria for quality assessment of St. Lawrence River sediment. Environment Canada, Ottawa 
Environment Canada, 2007. Criteria for the assessment of sediment quality in Quebec and application frameworks: Prevention, dredging and remediation.

Evers, D.C., Clair, T.A., 2005. Mercury in northeastern North America: a synthesis of existing databases. Ecotoxicology: 14:7-14.

Fitzgerald WF, Engstrom DR, Mason RP, Nater EA., 1998. The case for atmospheric mercury contamination in remote areas. Environ. Sci. Technol. 32:1-7.

Fleck, J.A., Alpers, C.N., Marvin-DiPasquale, M., Hothem, R.L., Wright, S.A., Ellett, K., et al., 2011. The effects of sediment and mercury mobilization in the South Yuba River and Humbug Creek Confluence Area, Nevada County, California-Concentrations, speciation, and environmental fate, Part 1-Field characterization: U.S. Geological Survey Open-File Report 2010-1325A, 104 p., http://pubs.usgs.gov/of/2010/1325A.

Gamby, R.L.; Hammerschmidt, C.R. Costello, D.M.; Lamborg, C.H.; Runkle, J.R., 2015. Deforestation and cultivation mobilize mercury from topsoil. Sci. Total Environ. 532:467-473

Gilmour, C.C., Riedel, G.S., Ederington, M.C., Bell, J.T., Benoit, J.M., Gill, G.A., Stordal, M.C., 1998. Methylmercury concentrations and production rates across a tropic gradient in the northern Everglades. Biogeochem. 40:327-45.

Gray, J.E., Theodorakos, P.M., Bailey, E.A., and Turner, R.R., 2000. Distribution, speciation, and transport of mercury in stream-sediment, stream-water, and fish collected near abandoned mercury mines in southwestern Alaska, USA. Sci. Total Environ. 260 (1-3):21-33.

Gray, J.E., Hines, ME., Goldstein, H.L., Reynolds, R.L., 2014. Mercury deposition and methylmercury formation in Narraguinnep Reservoir, southwestern Colorado, USA. Applied Geochem. 50:82-90.

Grosbois, C.A., Horowitz, A.J., Smith, J.J., Elrick, K.A., 2000. The effect of mining and related activities on the sediment-trace element geochemistry of Lake Coeur d'Alene, Idaho, USA. part III. Downstream effects: the Spokane River basin. Hydrol. Proc. 15:855-75.

Hall, B.D., Aiken, G.R., Krabbenhoft, D.P., Marvin-DiPasquale, M., Swarzenski, C.M., 2008. Wetlands as principal zones of methylmercury production in southern Louisiana and the Gulf of Mexico region. Environ. Pollut. 154(1):124-34.

Hall, B.D., St. Louis, V.L., Rolfhus, K.R., Bodaly, R.A., Beaty, K.G., Paterson, M.J., Cherewyk, K.A., 2005. Impacts of reservoir creation on the biogeochemical cycling of methyl mercury and total mercury in boreal upland forests. Ecosystems 8: 248-66.

Heim, W.A., Coale, K.H., Stephenson, M., Choe, K-Y., Gill, G.A., Foe, C., 2007. Spatial and habitat based variations in total and methyl mercury concentrations in surficial sediments in the San Francisco Bay-Delta. Environ. Sci. Technol. 41:3501-7.

Héon, D. (compiler), 2003. Yukon Regional Geochemical Database 2003 - Stream sediment analyses. Exploration and Geological Services Division, Yukon Region, Indian and Northern Affairs Canada.

Horowitz, A.J., Stephens, V.C., 2008. The effects of land use on fluvial sediment chemistry for the conterminous U.S. - Results from the first cycle of the NAWQA Program-Trace and major elements, phosphorus, carbon, and sulfur: Sci. Total Environ., 400 (1-3):290-314.

Hsu-Kim, H., Kucharzyk, K.H., Zhang, T., Deshusses, M.A., 2013. Mechanisms regulating mercury bioavailability for methylating microorganisms in the aquatic environment: a critical review. Environ. Sci. Technol. 47:2441-56. 
Hunerlach, M.P., Alpers, C.N., 2003. Studies of mercury contamination from gold mining-Mercury contamination from hydraulic gold mining in the Sierra Nevada, California, in Gray, J.E., ed., Geologic studies of mercury by the U.S. Geological Survey: U.S. Geological Survey Circular 1248, p. 23-27, http://pubs.usgs.gov/circ/2003/c1248.

Hunerlach, M.P., Alpers, C.N., Marvin-DiPasquale, M., Taylor, H.E., De Wild, J.F., 2004. Geochemistry of mercury and other trace elements in fluvial tailings upstream of Daguerre Point Dam, Yuba River, California, August 2001: U.S. Geological Survey Scientific Investigations Report 2004-5165, 66 p.

Jonsson, S., Skyllberg, U., Nilsson, M.B., Westlund, P., Shchukarev, A., Lundberg, E., Björn, E., 2012. Mercury methylation rates for geochemically relevant Hgll species in sediments. Environ. Sci. Technol. 46:11653-9.

Kannan, K., Smith, R.G. Jr., Lee, R.F., Windom, H.L., Heitmuller, P.T., Macauley, J.M., Summers, J.K., 1998. Distribution of Total mercury and methyl mercury in water, sediment, and fish from South Florida estuaries. Arch. Environ. Contam. Toxicol. 34, 109-18.

Kelly, C.A., Rudd, J.M., St Louis, V., Heyes, A., 1995. Is total mercury concentration a good predictor of methyl mercury concentration in aquatic systems? Water, Air, and Soil Pollut. 80: 715-24.

Krabbenhoft, D.P., Wiener, J.G., Brumbaugh, W.G., Olson, M.L., DeWild, J.F., Sabin, T.J., 1999. A National pilot study of mercury contamination of aquatic ecosystems along multiple gradients, in Morganwalp, D.W., and Buxton, H.T., eds., U.S. Geological Survey Toxic Substances Hydrology Program-Proceedings of the Technical Meeting, Charleston, South Carolina, March 8-12, 1999_Volume 2 of 3-Contamination of Hydrologic Systems and Related Ecosystems: U.S. Geological Survey Water-Resources Investigations Report 99-4018-B, p. 147-160, http://toxics.usgs.gov/pubs/wri99-4018/Volume2/sectionB/2301_Krabbenhoft/index.html.

Lambertsson, L.; Nilsson, M., 2006. Organic material: The primary control on mercury methylation and ambient methyl mercury concentrations in estuarine sediments. Environ. Sci. Technol. 40:1822-9.

Lawrence, S.J., 2003. Mercury in the Carson River Basin, Nevada, in Gray, J.E., (Ed.), Geologic studies of mercury by the U.S. Geological Survey: U.S. Geological Survey Circular 1248, p. 29-33, http://pubs.usgs.gov/circ/2003/c1248.

Long E.R., Morgan, L.G., 1991. The potential for biological effects of sediment-sorbed contaminants tested in the National Status and Trends Program. NOAA Technical Memorandum NOS OMA 52, National Oceanic and Atmospheric Administration, Seattle, WA, 175 pp + appendices

Long, E.R., Field, L.J., MacDonald, D.D., 1998. Predicting toxicity in marine sediments with numerical sediment quality guidelines. Environ. Toxicol. Chem. 17:714-27.

Long, E.R., MacDonald, D.D., Cubbage, J.C., Ingersoll, C.G., 1998. Predicting the toxicity of sedimentassociated trace metals with simultaneously extracted trace metal: acid-volatile sulfide concentrations and dry weight-normalized concentrations: a critical comparison. Environ. Toxicol. Chem. 17:972-4.

Loukmas, J.J., Quinn, S.O., Bloomfield, J., 2006. Total and methyl mercury in the Neversink Reservoir watershed. Report.

MacDonald, D.D., Ingersoll, C.G., Berger, T.A., 2000. Development and evaluation of consensus-based sediment quality guidelines for fresh water ecosystems. Arch. Environ. Contam. Toxicol. 39:20-31. 
Marvin-DiPasquale, M., Lutz, M.A., Brigham, M.E., Krabbenhoft, D.P., Aiken, G.R., Orem, W.H., Hall, B.D., 2009. Mercury cycling in stream ecosystems. 2. Benthic methylmercury production and bed sediment-pore water partitioning. Environ. Sci. Technol. 43:2726-32.

Marvin-DiPasquale, M., Windham-Myers, L., Agee, J.L., Kakouros, E., Kieu, L.H., Fleck, J., Alpers, C.N., Stricker, C., 2014. Methylmercury production in sediment from agricultural and non-agricultural wetlands in the Yolo Bypass, California. Sci. Total Environ. 484:288-99.

Marvin-DiPasquale, M., Agee, J.L., Bouse, R.M., Jaffe, B.E., 2003. Microbial cycling of mercury in contaminated pelagic and wetland sediments of San Pablo Bay, California: Environ. Geol. 43(3):2607.

Marvin-DiPasquale, M., Agee, J.L., Kakouros, E., Kieu, L.H., Fleck, J.A., Alpers, C.N., 2011. The effects of sediment and mercury mobilization in the South Yuba River and Humbug Creek confluence area, Nevada County, California-Concentrations, speciation and environmental fate-Part 2Laboratory Experiments: U.S. Geological Survey Open-File Report 2010-1325B, 53 p., http://pubs.usgs.gov/of/2010/1325B.

Marvin-DiPasquale, M., Cox, M.H., 2007. Legacy mercury in Alviso Slough, South San Francisco Bay, California-Concentration, speciation and mobility: U.S. Geological Survey Open-File Report 20071240, 99 p., http://pubs.usgs.gov/of/2007/1240/.

Massachusetts Department of Environmental Protection, 2002. Freshwater sediment screening benchmarks for use under the Massachusetts Contingency Plan. Massachusetts Department of Environmental Protection, Technical Update-May. Available at: /http://www.mass.gov/dep/cleanup/laws/sedscrn.docS.

Mergler D., Anderson H.A., Chan L.H.M., Mahaffey K.R., Murray M., Sakamoto M., Stern A.H., 2007. Methylmercury exposure and health effects in humans: a worldwide concern. Ambio 36:3.

Mitchell, C.P.J., Branfireun, B., Kolka. R.K., 2009. Methylmercury dynamics at the upland-peatland interface: Topographic and hydrogeochemical controls. Water Resources Research 45: W02406, doi:10.1029/2008WR006832

Morel, F. M. M., Kraepiel, A. M. L., Amyot, M., 1998. The chemical cycle and bioaccumulation of mercury. Ann. Rev. Ecol. System. 29:543-66.

Nater, E.A.,Grigal, D.F., 1992. Regional trends in mercury distribution across the Great Lakes States, north central USA. Nature 358:139-41.

Negra, C., Lambert, K.F., 2009. MercNet-Establishing a comprehensive national mercury monitoring network: U.S. Environmental Protection Agency, EPA 430-K-09-001, 35 p.

Obrist, D., Pearson, C., Webster, J., Kane, T., Lin, C.J., Aiken, G.R., Alpers, C.N., 2016. Terrestrial mercury in the western United States: spatial distribution defined by land cover and plant productivity. Sci Total Environ. [in this issue]

Ontiveros-Cuadras, J.F., Ruiz-Fernández, A.C., Sanchez-Cabeza, J.A., Pérez-Bernal, L.H., Sericano, J.L., Preda, M., et al., 2014. Trace element fluxes and natural potential risks from 210Pb-dated sediment cores in lacustrine environments at the Central Mexican Plateau. Sci. Total Environ. 468-469:677-87

Persaud, D., Jaagumagi, R., Hayton, A., 1993. Guidelines for the protection and management of aquatic sediment quality in Ontario. Water Resources Branch. Ontario Ministry of the Environment, Toronto, $27 \mathrm{pp}$. 
Phillips, V.J.A., St. Louis, V.L., Cooke, C.A., Vinebrooke, R.D., Hobbs, W.O., 2011. Increased Mercury Loadings to Western Canadian Alpine Lakes over the Past 150 Years. Environ. Sci. Technol. 45:20427. dx.doi.org/10.1021/es1031135.

Prior, G.J., McCurdy, M.W., Day, S.J.A., Nicoll, T.J., Friske, P.W.B., McNeil, R.J. Waight, B.M., 2005. Preliminary release of selected stream sediment and water geochemical results from the 2004 National Geochemical Reconnaissance survey in the Buffalo Head Hills, Northern Alberta (parts of NTS 84B, 84C, 84F and 84G); Alberta Energy and Utilities Board, EUB/AGS Geo-Note 2005-03, 59 p.

Randall, P.M., Chattopadhyay, S., 2013. Mercury contaminated sediment sites-An evaluation of remedial options. Environ. Res. 125:131-49.

Rytuba, J.J., 2003. Mercury from mineral deposits and potential environmental impact. Environ. Geol. 43:326-38.

Singer, M.B., Aaltoc, R., Jamesd, L.A., Kilhame, N.E., Higsona, J.L., Ghoshalf S., 2013. Enduring legacy of a toxic fan via episodic redistribution of California gold mining debris. PNAS Available at: www.pnas.org/cgi/content/short/1302295110.

Smith, S.L., MacDonald, D.D., Keenleyside, K.A., Ingersoll, C.G., Field, J., 1996. A preliminary evaluation of sediment quality assessment values for freshwater ecosystems. J. Great Lakes Res. 22624-638.

Smith, D.B., Cannon, W.F., Woodruff, L.G., Solano, F., Kilburn, J.E., Fey, D.L., 2013. Geochemical and mineralogical data for soils of the conterminous United States. U.S. Geological Survey Data Series. 801, pp. 19.

Scudder, B.C., Chasar, L.C., Wentz, D.A., Bauch, N.J., Brigham, M.E., Moran, P.W., Krabbenhoft, D.P., 2009. Mercury in Fish, Bed Sediment, and Water from Streams across the United States, 1998-2005. U.S. Geological Survey. p. 74.

Skyllberg, U., Xia, K., Bloom, P.R., Nater, E.A., Bleam, W.F., 2000. Binding of mercury(II) to reduced sulfur in soil organic matter along upland-peat soil transects. J. Environ. Qual. 29:855-65.

Sunderlund, E.M., Gobas, F., Branfireun, B.A., Heyes A., 2006. Environmental controls on the speciation and distribution of mercury in coastal sediments. Mar. Chem. 102:111-23.

Taylor, D.L., Linehan, J.C., Murray, D.W., Prell, W.L., 2012. Indicators of sediment and biotic mercury contamination in a southern New England estuary. Mar. Pollut. Bull. 64(4): 807-19. doi:10.1016/j.marpolbul.2012.01.013

Ullrich, M., Tanton, T.W., Abdrashitova, S.A., 2001. Mercury in the aquatic environment: a review of factors affecting methylation. Crit. Rev. Environ. Sci. Technol. 31 (3):241-93.

Wells, D., Hill, J., 2004. A synthesis of sediment chemical contaminant studies in the Maryland Coastal Bays. Maryland's Coastal Bays-Ecosystem Health Assessment. Available at: /http://www.dnr.state.md.us/coastalbays/publications/Chapter5.2.pdfS., 2004

Wentz, D.A., Brigham, M.E., Chasar, L.C., Lutz, M.A., Krabbenhoft, D.P., 2014. Mercury in the Nation's streams - Levels, trends, and implications: U.S. Geological Survey Circular 1395, 90 p., http://dx.doi.org/10.3133/cir1395.

Wiener, J.G., Krabbenhoft, D.P., Heinz, G.H., Scheuhammer, A.M., 2003. Ecotoxicology of mercury, in Hoffman, D.J., B.A. Rattner, G.A. Burton, Jr., and J. Cairns, Jr., eds., Handbook of Ecotoxicology (2nd ed.): Boca Raton, Florida, CRC Press, chap. 16, p. 409-463.

Wiener, J.G., Evers, D.C., Gay, D.A., Morrison, H.A., Williams, K.A., 2012. Mercury contamination in the Laurentian Great Lakes region: Introduction and overview. Environmental Pollution 161:243-51. 
Windham-Myers, L., Marvin-DiPasquale, M., Stricker, C., Agee, J.L., Kieu, L.H., and Kakouros, E., 2014. Mercury cycling in agricultural and managed wetlands of California, USA-Experimental evidence of vegetation-driven changes in sediment biogeochemistry and methylmercury production: Sci. Total Environ. 484:300-7. 

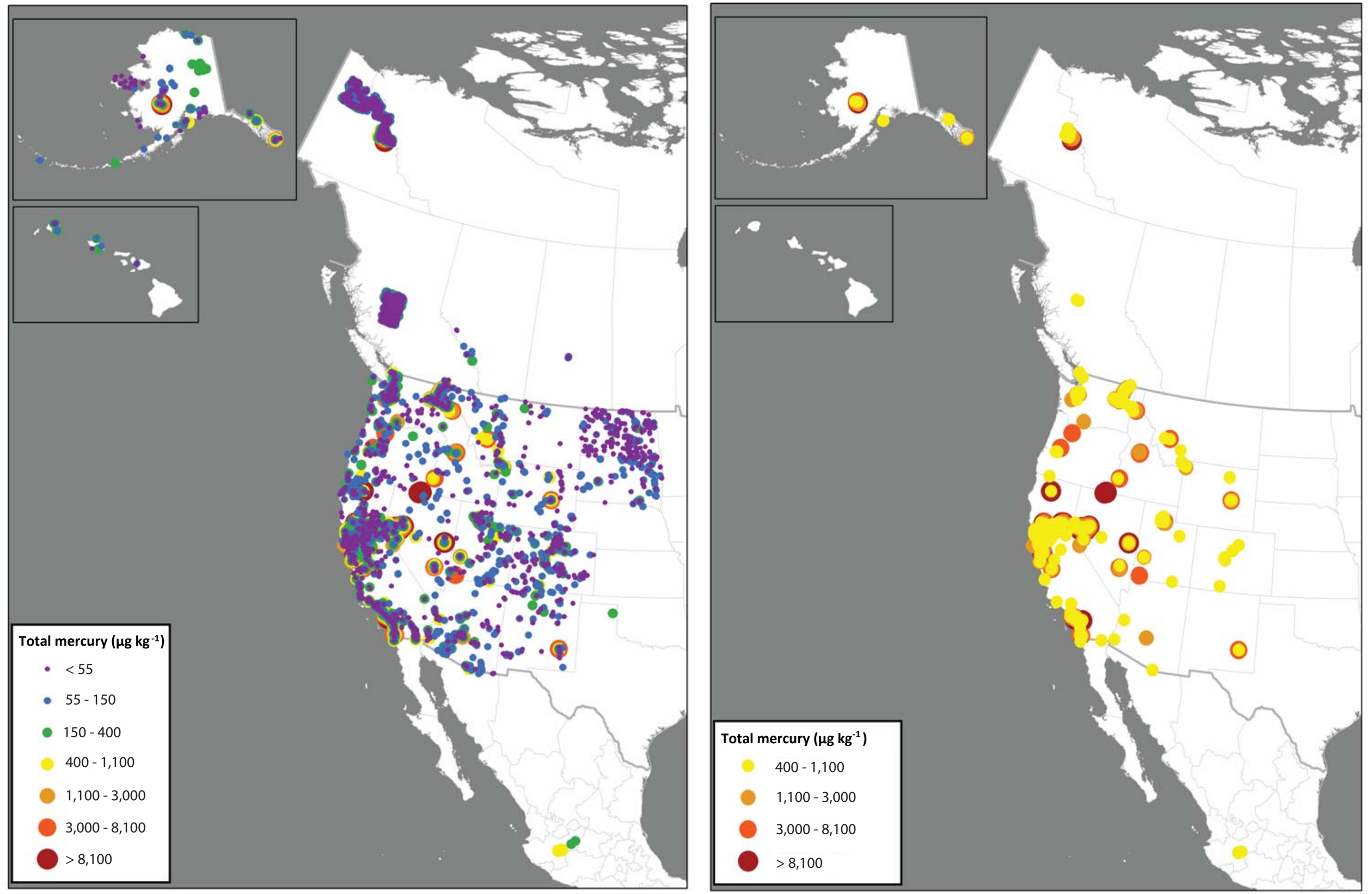

Figure 1. Map showing the distribution of THg concentrations of individual aquatic bed sediment samples across the western North American landscape. Figure A shows concentration data for all samples with low values overlaid on top of higher values. Figure B shows data for samples with concentrations greater than $400 \mu \mathrm{g} \mathrm{kg}-1$ for easier visualization of the higher concentration locations. Symbol size and color are for visualization purposes only. Symbol colors reflect regulatory targets and benchmark screening levels, as summarized in Table 1, but also closely reflect the natural log distribution across the entire dataset. Despite the linkage to regulatory and benchmark concentrations, the concentration bins used in this assessment are not meant to imply risk but to provide a standardized framework for comparison. 


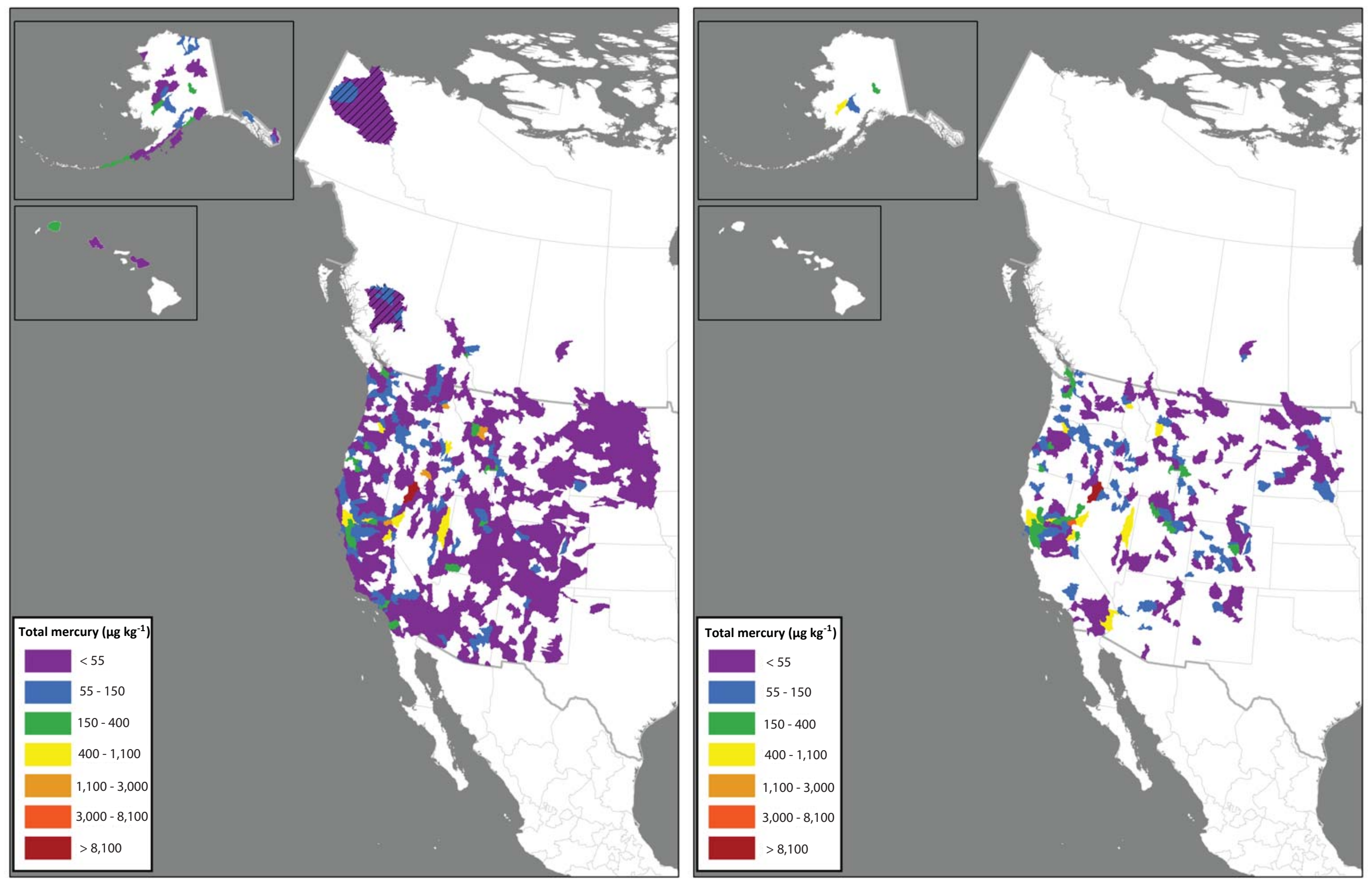

Figure 2. Map showing the spatial distribution of HUC8-based least squares mean THg concentrations for A) the complete THg data set and B) the subset of the THg data where MeHg was also measured. Cross-hatching indicates HUCs where all samples were sieved. 

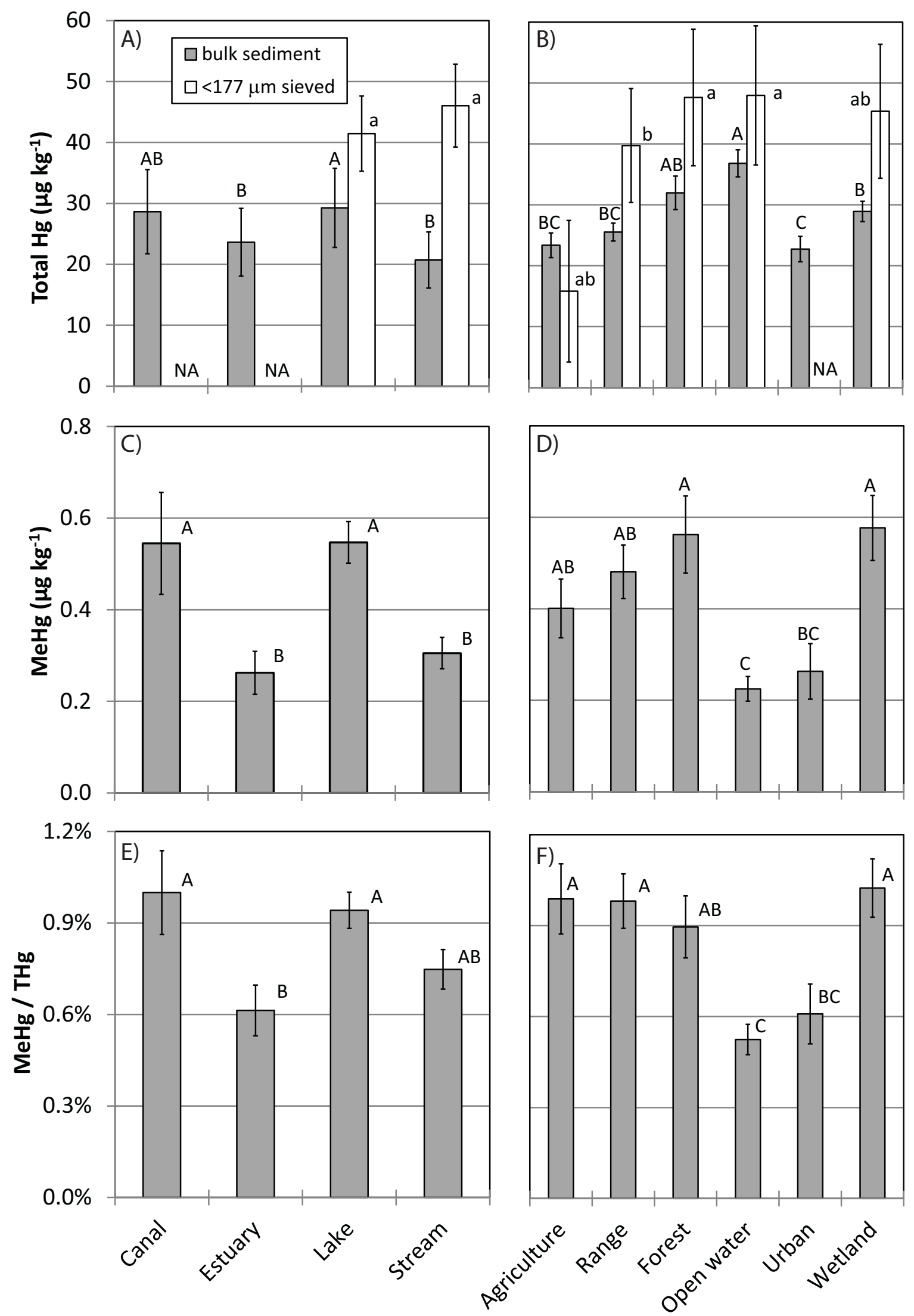

Figure 3. Comparison of least squares mean concentration for A) THg by feature type, B) THg by environmental setting, C) MeHg by feature type, D) MeHg by environmental setting, E) $\mathrm{MeHg} / \mathrm{THg}$ by feature type, and F) $\mathrm{MeHg} / \mathrm{THg}$ by environmental setting. Different letters next to the bars on the chart indicate significant differences between categories, capital letters were used for the bulk data set and small letters were used for the sieved data set. 


\section{A. Methylmercury}

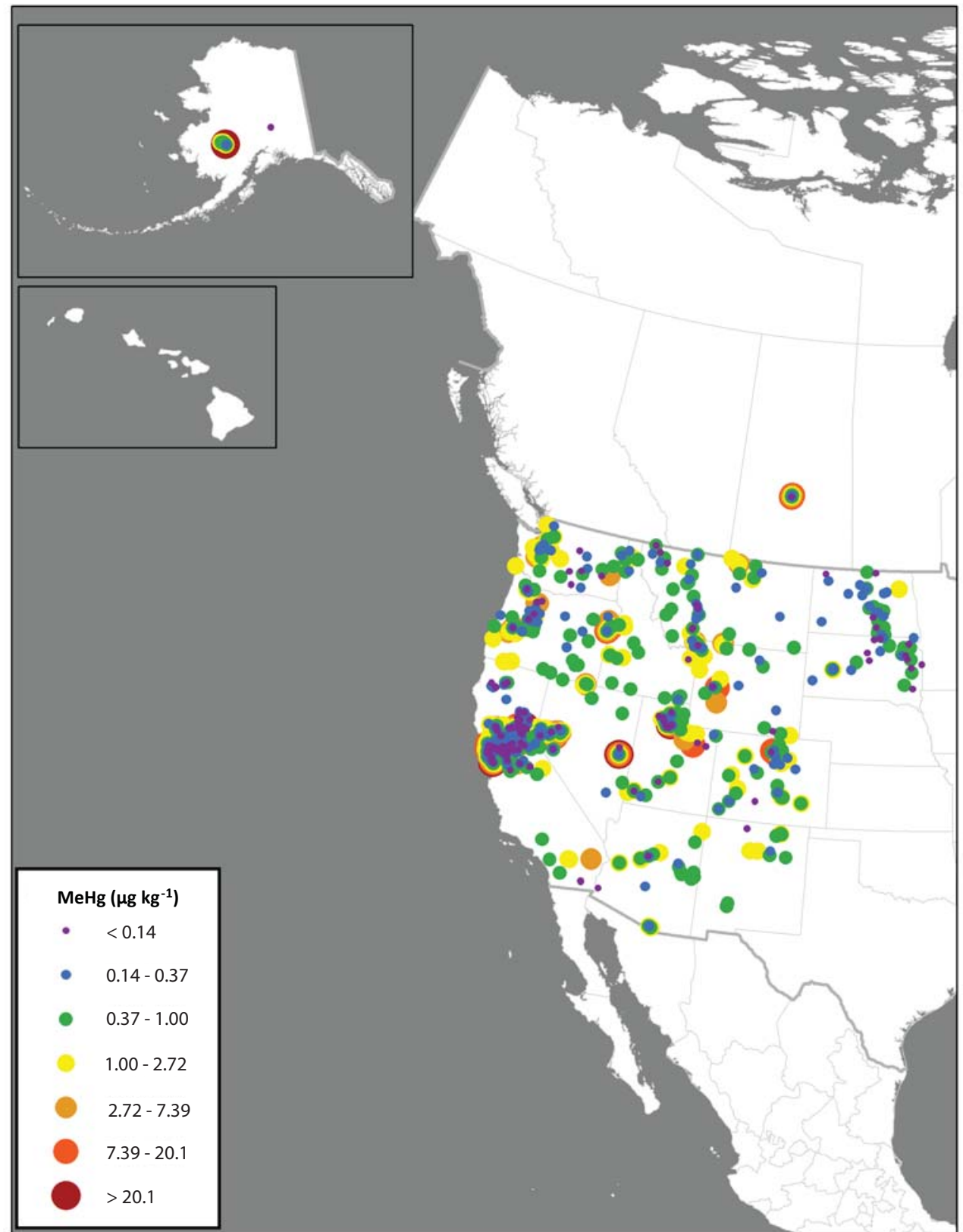

B. Methylmercury / Total Mercury

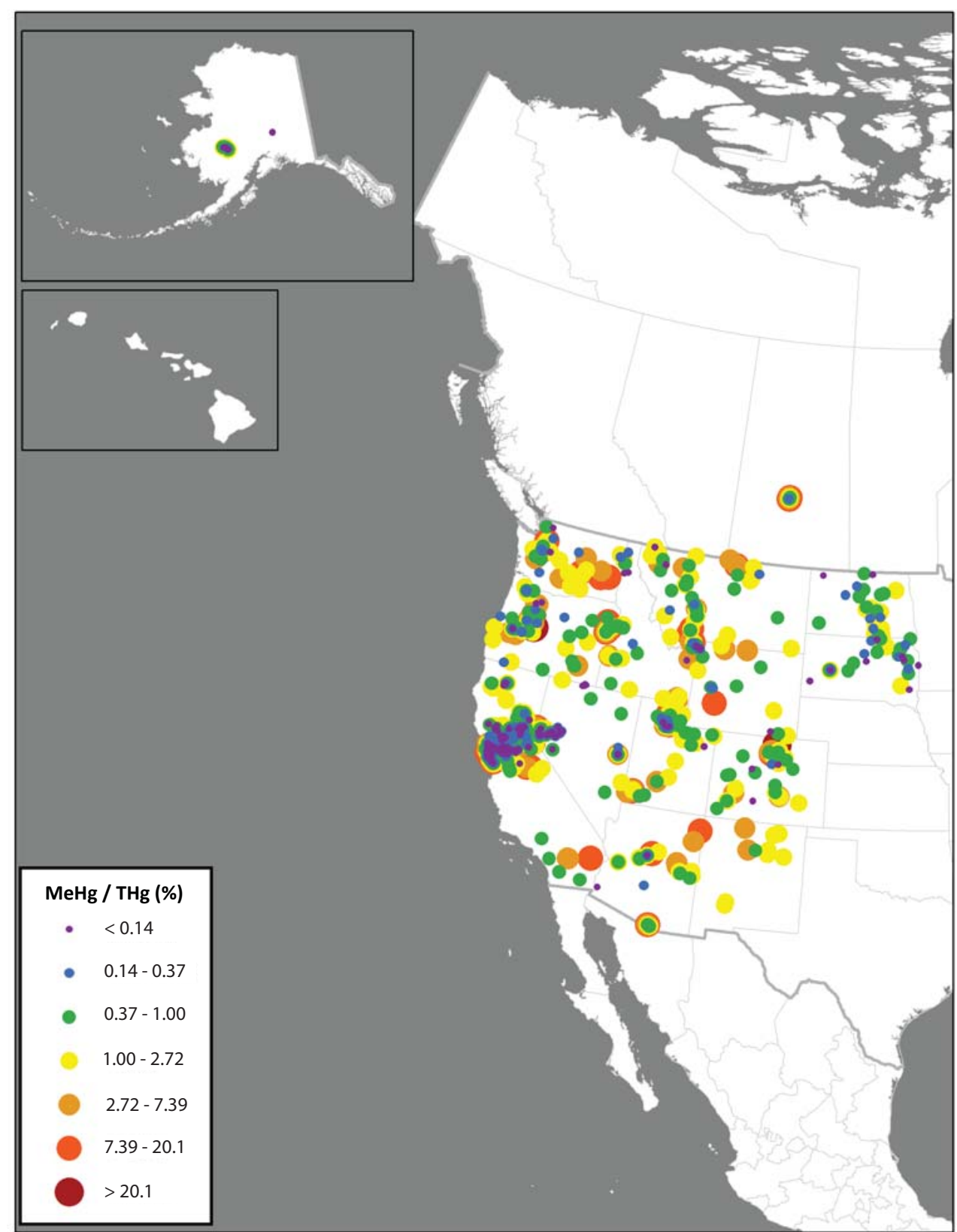

Figure 4. Map showing the spatial distribution of individual sample results for A) surface sediment MeHg concentration and B) the ratio of MeHg to $\mathrm{THg}$, shown as a percentage, across western North America. 


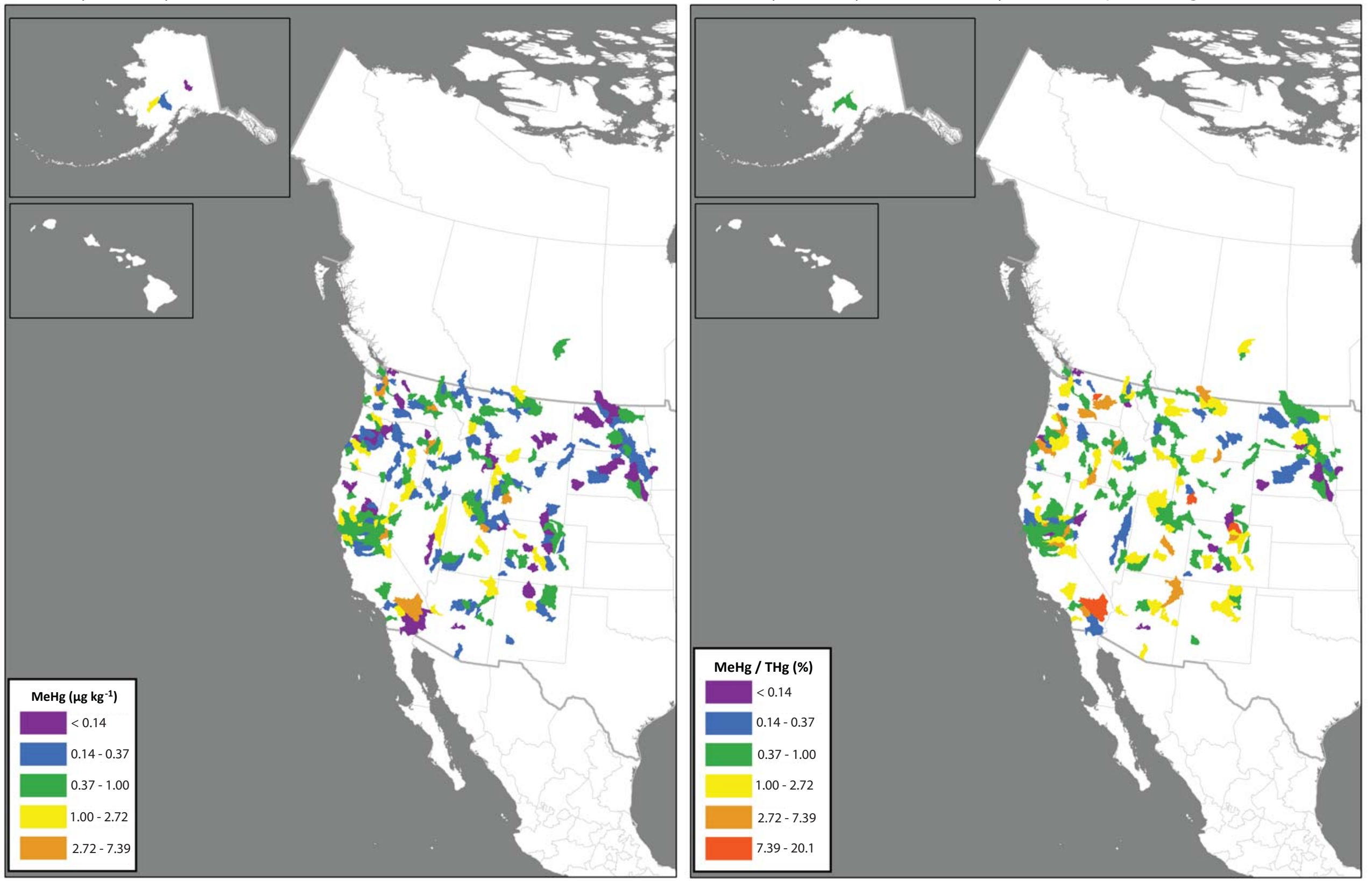

Figure 5. Map showing the spatial distribution of HUC8 least squares mean for A) MeHg concentrations and B) the ratio of MeHg to THg, shown as a percentage. 


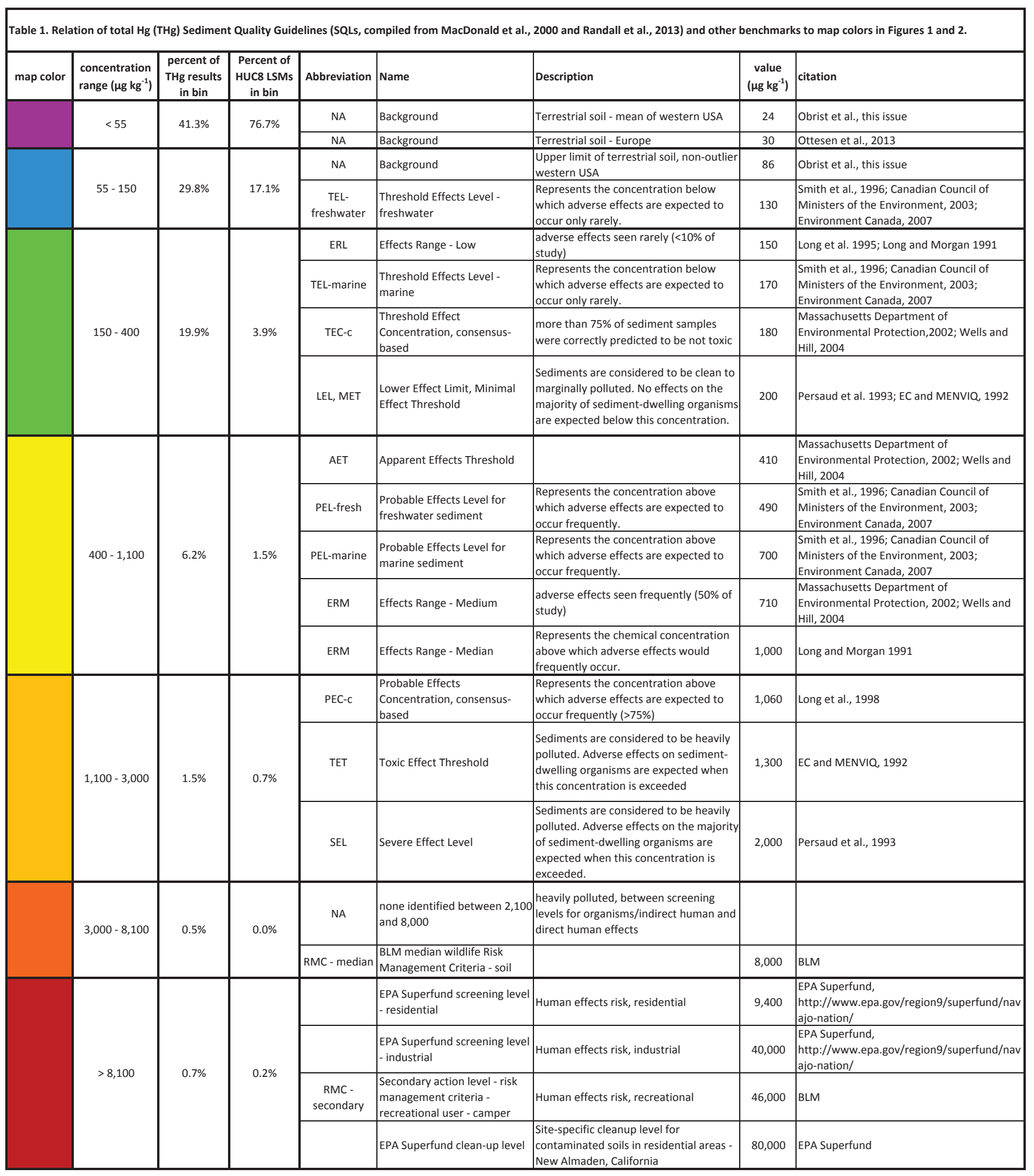



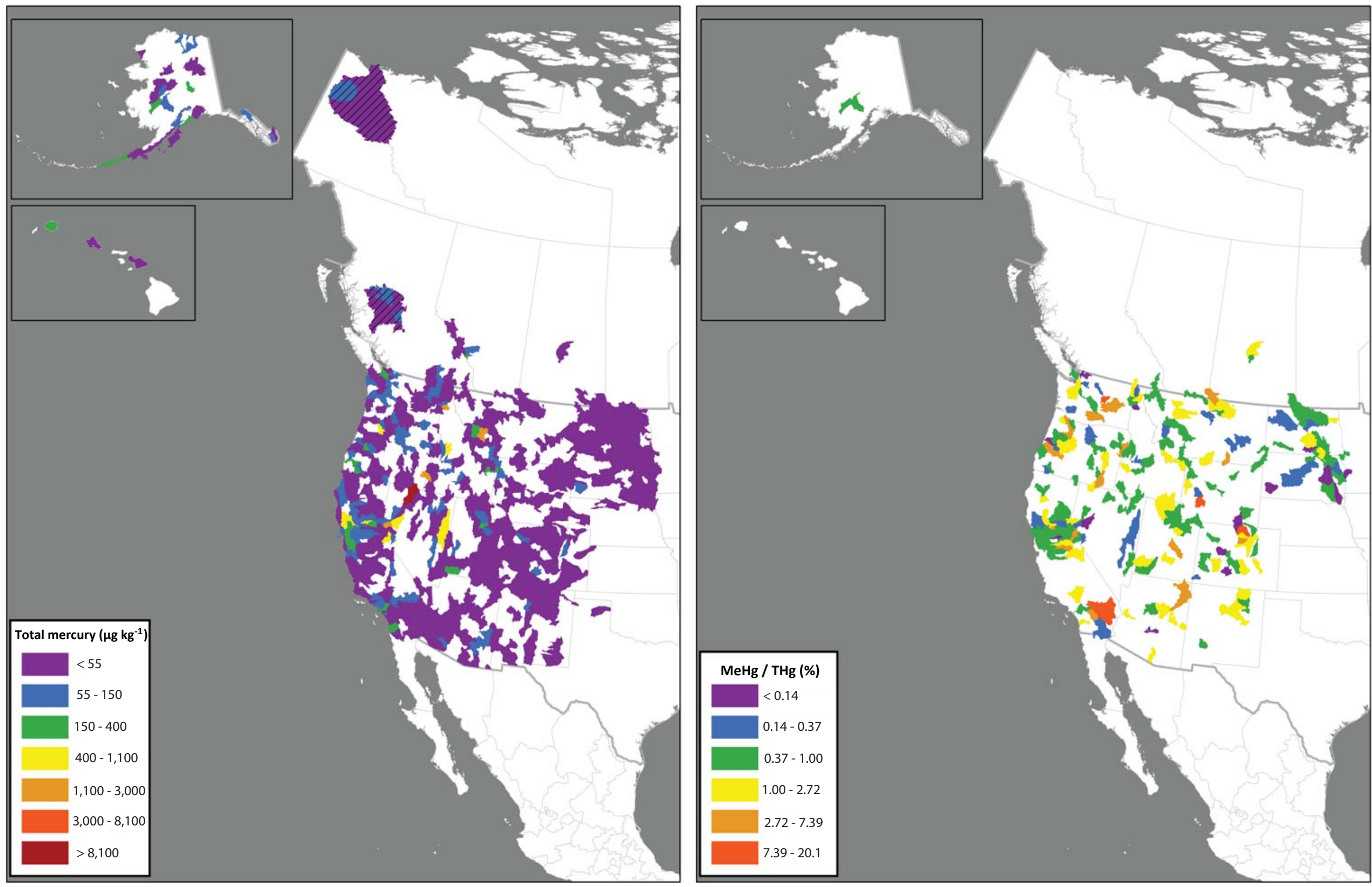